correct it. However, as such corrections are not then transferred to the original transcript it may be difficult for the Refugee Status Advisory Committee members making the decision to properly utilize the corrections.

Under the transitional and ideal programme, the transcript would still be prepared for consideration by the Refugee Status Advisory Committee and Refugee Review Board in oral hearing referrals and in cases where the interviewing officer recommends rejection as being manifestly unfounded. However, while the claimant is entitled to receive the transcript, the time period given to correct it prior to its being sent to the Refugee Status Advisory Committee or Refugee Review Board could be eliminated. Persons referred for an oral hearing could present corrections at the outset of the hearing. Persons who have been determined to have frivolous claims could append corrections to the transcript as part of their declarations under oath to the Board.

Reasons Provided for Rejected Claims In principle, "The claimant should be provided with the reasons for the Committee's decision at the time that he/she is notified of the decision." However, the reasons are incomplete and often irrelevant. They are often stock reasons for rejection without any real analysis of the claim.

Under the recommended procedure, the Refugee Review Board would be required to give reasons for its decisions. Under the transitional procedure, the Refugee Status Advisory Committee would provide reasons when a claim is rejected after an oral hearing or because it is determined to be manifestly unfounded.

\footnotetext{
*This is an edited version of a report prepared in April 1983 by a Delegation of Concerned Legal,
} Church and Humanitarian Organizations.

\title{
Books and Periodicals
}

The World Refugee Survey 1983, 25th anniversary issue, contains articles on international and U.S. definitions of refugees, repatriation as a solution to refugee situations, resettlement in the U.S. and Australia, emigration of Soviet Jews, and congressional perspectives on refugee policy. Country-by-country descriptions of refugee situations in Africa, East Asia, the Pacific, Europe, Latin America and the Caribbean, the Middle East, and Southeast Asia are provided. Extensive statistical information includes numbers of refugees in need and resettled and contributions by international refugee aid agencies in 1982.

\section{* * *}

Escape to Freedom: The Story of the International Rescue Committee, by Aaron Levenstein, has been published to commemorate the 50th anniversary of the IRC. Originally founded to help those fleeing Hitler's Germany, the IRC has continued its work since then, tirelessly helping refugees from all over the world. In the course of attempting to sum up IRC's diverse experience, the book notes the many invaluable contributions refugees have made over the years. The late Reinhold Niebuhr, prominent theologian and one of IRC's chairmen, recognized the value of refugee work in a quote recorded near the end of the book: "Never before in the 20th century has any nation been presented a greater opportunity to contribute so directly to the preservation of invaluable creative sources and to the enrichment of its own civilization." 338 pages. Greenwood Press, 88 Port Road West, P.O. Box 5007, Westport, CT. 06881 U.S.A. (203) 226-3581. Hardcover $\$ 29.95$.

\section{New Indochina Studies Program}

The Committee on Southeast Asia jointly sponsored by the Social Science Research Council and the American Council of Learned Societies - is pleased to announce a new Indochina Studies Program. The Program is intended to encourage and support research, writing, and the archiving of materials on Cambodia, Laos, and Vietnam, drawing on the knowledge and experience of the refugees who have left those three countries since 1975, and who are now residing in North America.

The Indochina Studies Program will sponsor an annual fellowship competition open to researchers, writers, journalists, artists, and other professionals and individuals. Fellows will be expected to produce a written product which will contribute to understanding the three countries, or the lives of specific people within them. Individual applicants must be residents of the United States or Canada. Joint projects involving one or more North American scholars and one or more refugees are encouraged. In these cases, at least one of the applicants must be a resident of North America. As needed, the Program will assist Fellows to obtain an academic affiliation for the period of the award.

Projects may be based on life histories, personal memoirs, focused interviews, studies of particular groups, the recording and analysis of oral, ritual, performance, and other artistic traditions, or written literatures. Specifically excluded are projects concerned with the American experience in Indochina, and the experience of Indochinese refugees in North America. Program Fellows will be expected to place project materials in a selected archive to help assure their availability for others in the future.

Fellowships may be short-term, or for up to as much as 12 months. Projects should be designed to be completed within a single year. Skill in the relevant language(s) will be a major criterion in the selection process. Fellowships may include full-time or part-time maintenance, essential travel and research expenses, as well as summer language training or refresher courses in Hmong, Khmer, Lao, or Vietnamese. Supplemental funding for archival purposes will be considered. In exceptional cases, awards may be renewed for a second year, and support may be provided for a full year of language training in Khmer or Lao if in preparation for a subsequent research and writing project. The maximum award for any project will be $\$ 25,000$.

For application materials or other inquiries, please send the information requested above to the Indochina Studies Program, Social Science Research Council, 605 Third Avenue, New York, New York 10158. 